\title{
Fluid flow in the northern Broad Fourteens Basin during Late Cretaceous inversion
}

\section{Bouw ${ }^{1,2}$ \& G.H.P. Oude Essink ${ }^{3}$}

${ }^{1}$ Corresponding author, e-mail: L.Bouw@CiTG.TUDelft.nl

2 Delft University of Technology, Hydrology \& Ecology Group, P.O. box 5048, 2600 GA Delft, the Netherlands

3 Netherlands Institute of Applied Geoscience TNO - National Geological Survey, P.O. box 80015, 3508 TA Utrecht, the Netherlands (e-mail: g.oudeessink@nitg.tno.nl) \& Vrije Universiteit Amsterdam, Faculty of Earth and Life Sciences, De Boelelaan 1085, 1081 HV Amsterdam, the Netherlands, e-mail: oudg@geo.vu.nl

Manuscript received: February 2002; accepted: January 2003

\begin{abstract}
A basin-scale hydrogeological study of the inverted northern Broad Fourteens Basin, Netherlands offshore, has resulted in a reconstruction of geological evolution, an estimate of Late Cretaceous topography and model scenarios of syn-inversion meteoric water infiltration. This study was performed in the scope of a basin-scale analysis of the hydrogeological setting and hydrodynamic evolution of the Broad Fourteens Basin. This analysis is aimed at obtaining quantitative knowledge of depositional history and hydrogeological parameters, and qualitative knowledge of hydrodynamic evolution of the Broad Fourteens Basin from Carboniferous to present-day. We present an overview of the tectonic and depositional history, the most likely hydrogeological setting and model scenarios of Late Cretaceous meteoric water infiltration in the northern Broad Fourteens area.

We constructed a detailed south-west north-east geological cross-section of the present-day northern Broad Fourteens Basin, and reconstructed Late Cretaceous basin geometry and topography. Using this geometry in a numerical model of density-dependent topography-driven fluid flow, we modelled several scenarios of meteoric water infiltration with estimated ranges of basin-scale permeabilities and water table head. Results indicate that a deep freshwater lens was developed during Late Cretaceous inversion, if the basin-scale hydraulic conductivity of the Rijnland and Altena Groups was at least $1 \cdot 10^{-9}$ to $1 \cdot 10^{-10} \mathrm{~m} / \mathrm{s}$, which is in general the highest value for claystones.
\end{abstract}

Keywords: basin inversion, Broad Fourteens Basin, meteoric water infiltration, Netherlands North Sea, numerical models, sedimentary basins

\section{Introduction}

The Broad Fourteens Basin is a north-west southeast trending structural element, situated in the southern North Sea, $\mathrm{K}$ and L quadrants Netherlands offshore (Fig. 1).

The basin was formed during the Mesozoic and it was filled dominantly with claystones (Fig. 2). The basin was subject to major inversion movements during the Late Cretaceous Sub-Hercynian phase and minor inversion movements during the Early Tertiary Laramide phase. Several publications describe the development and structural geology of the Broad Fourteens Basin in detail (i.e. Van Wijhe, 1987a, 1987b;
Dronkers \& Mrozek, 1991; Nalpas et al. 1995, 1996). The Broad Fourteens Basin is approximately $120 \mathrm{~km}$ long and $45 \mathrm{~km}$ wide. The south-west boundary is formed by a major graben fault, whereas the northeast boundary is formed by a gradual transition to the adjacent platform area. The northern Broad Fourteens Basin is affected especially by salt tectonics and salt diapirism, in contrast to the southern Broad Fourteens Basin where salt movements are less pronounced.

In this study, a detailed south-west north-east geological cross-section (Fig. 3) of the northern Broad Fourteens Basin was constructed, based on the seismic section SNST 83-04 (Van Wijhe, 1987b; Nopec, 


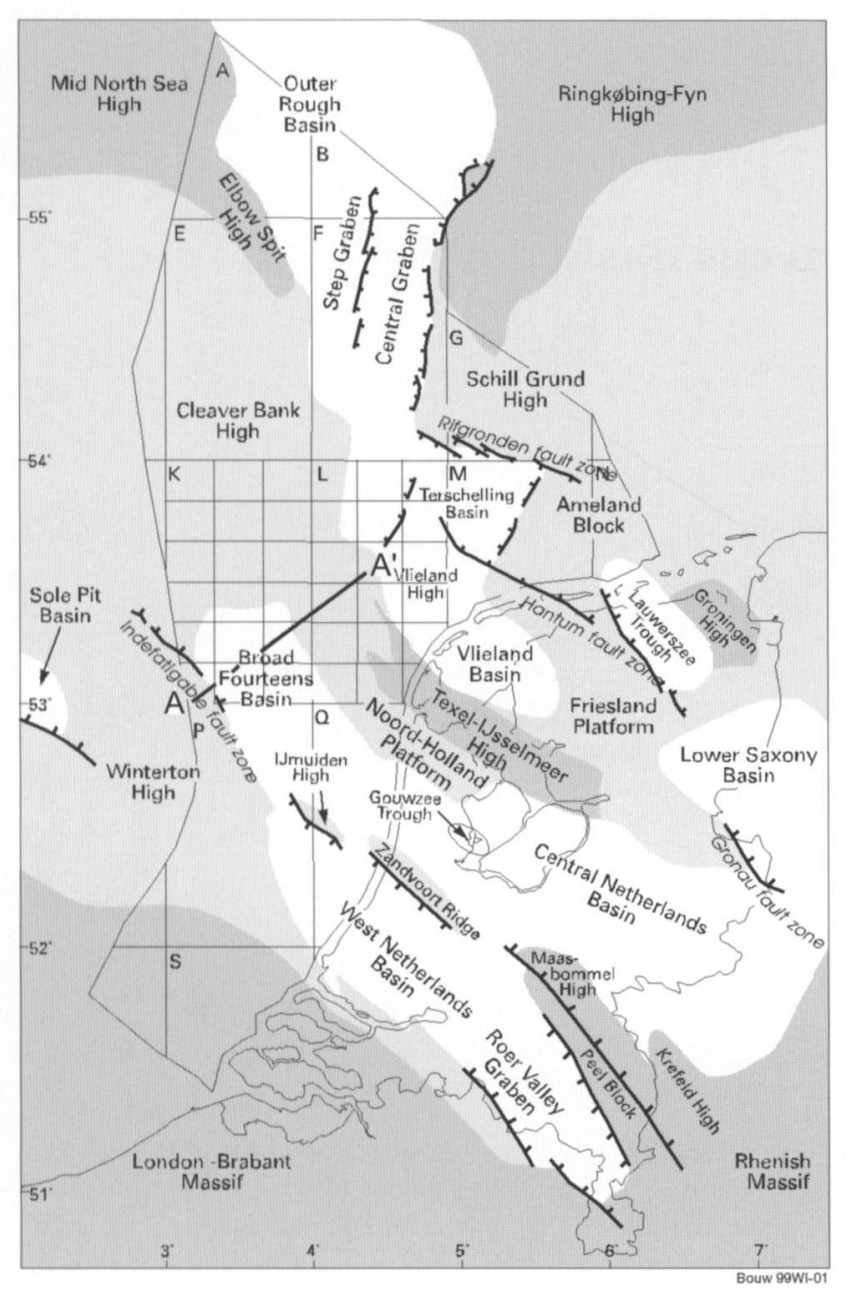

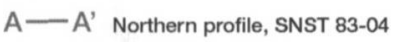
$100 \mathrm{~km}$

Fig. 1. Location of the Broad Fourteens Basin, Netherlands offshore (after Van Adrichem Boogaert \& Kouwe, 1993-1997). A-A' indicates the location of the geological cross-section.

1988) from the regional seismic survey by NOPEC/Geco-Prakla, regional geological data and well log data. The depositional history, structural geology and hydrodynamic evolution of the northern Broad Fourteens Basin are described, based on literature data and the constructed cross-section. The lithology, porosity, permeability, permeability anisotropy and (pre-erosional) thicknesses of stratigraphic units were derived from literature, well-logs, profile reconstruction and quantitative estimates. A Late Cretaceous topography was reconstructed, based on an uplift / denudation model. A Late Cretaceous basin geometry was reconstructed to study the possible extension of topography-driven meteoric water infiltration during the Late Cretaceous inversion phase. Infiltration was calculated with a basin-scale numerical model of density-dependent fluid flow, using the modelling package MOCDENS3D (Oude Essink, 1999, 2001).

Several scenarios were simulated with variations in basin-scale permeabilities (Fig. 4 and Table 1) and water table head, within the range of most likely values. The model was constructed to assess whether a freshwater lens was developed during inversion, and if so at which depth the steady-state fresh/salt water interface was located. Another issue of interest is the extent of the freshwater lens in the basin centre, as it may have reached and subroded (post-burial dissolved) uplifted Zechstein evaporites.

\section{Geological setting}

The Broad Fourteens Basin has undergone a complex geological evolution, which includes a Late Triassic to Jurassic rifting stage and a Late Cretaceous inversion event. Before basin development, a section of pre-rift Late Permian and Triassic strata with fairly uniform thickness was deposited in the future Broad Fourteens area (Fig. 2). In the Late Triassic and Jurassic, syn-rift siliciclastic sediments (that thicken basinward) were laid down. During the Late Kimmerian I phase in the Late Jurassic, erosion of the platform areas and locally minor erosion of the basin area occurred. The Late Kimmerian II erosional phase is significantly more important at the north-east platform than at the south-west platform in the study area. Large amounts of basin sediments were eroded during the Late Kimmerian II phase. After basin development and these erosional phases, post-rift Early Cretaceous sediments with uniform thickness covered both the former basin and platform areas. In the Late Cretaceous a thick interval of chalk of the Ommelanden Fm. was deposited on the platform areas flanking the Broad Fourteens area. A thin section of Ommelanden chalk may have accumulated in the centre of the Broad Fourteens area, prior to Late Cretaceous inversion. After this inversion, a thin layer of chalk of the Paleocene Ekofisk Fm. was deposited, most likely on both platform and former basin areas, followed by erosion in the basin centre and sedimentation of a thick layer of Tertiary to recent siliciclastics (Fig. 2). Below, we describe the lithology and depositional history of the Broad Fourteens Basin area from Carboniferous to recent times in more detail.

During the Silesian Late Variscan phase, an estimated 700-1,400 $\mathrm{m}$ of erosion of the Carboniferous Limburg Group occurred in the future Broad Fourteens area, and up to $600 \mathrm{~m}$ of erosion of the platform areas (Bouw, 1999). After this phase, about 200-340 $\mathrm{m}$ of Upper Rotliegend aeolian and fluvial sandstones and playa lake claystones were deposited (Fig. 3). The Upper Rotliegend sandstones have present-day porosity of about $10-15 \%$ and permeability of about $1 \cdot 10^{-6} \mathrm{~m} / \mathrm{s}$ (Roos \& Smits, 1983; Beekman et al., 


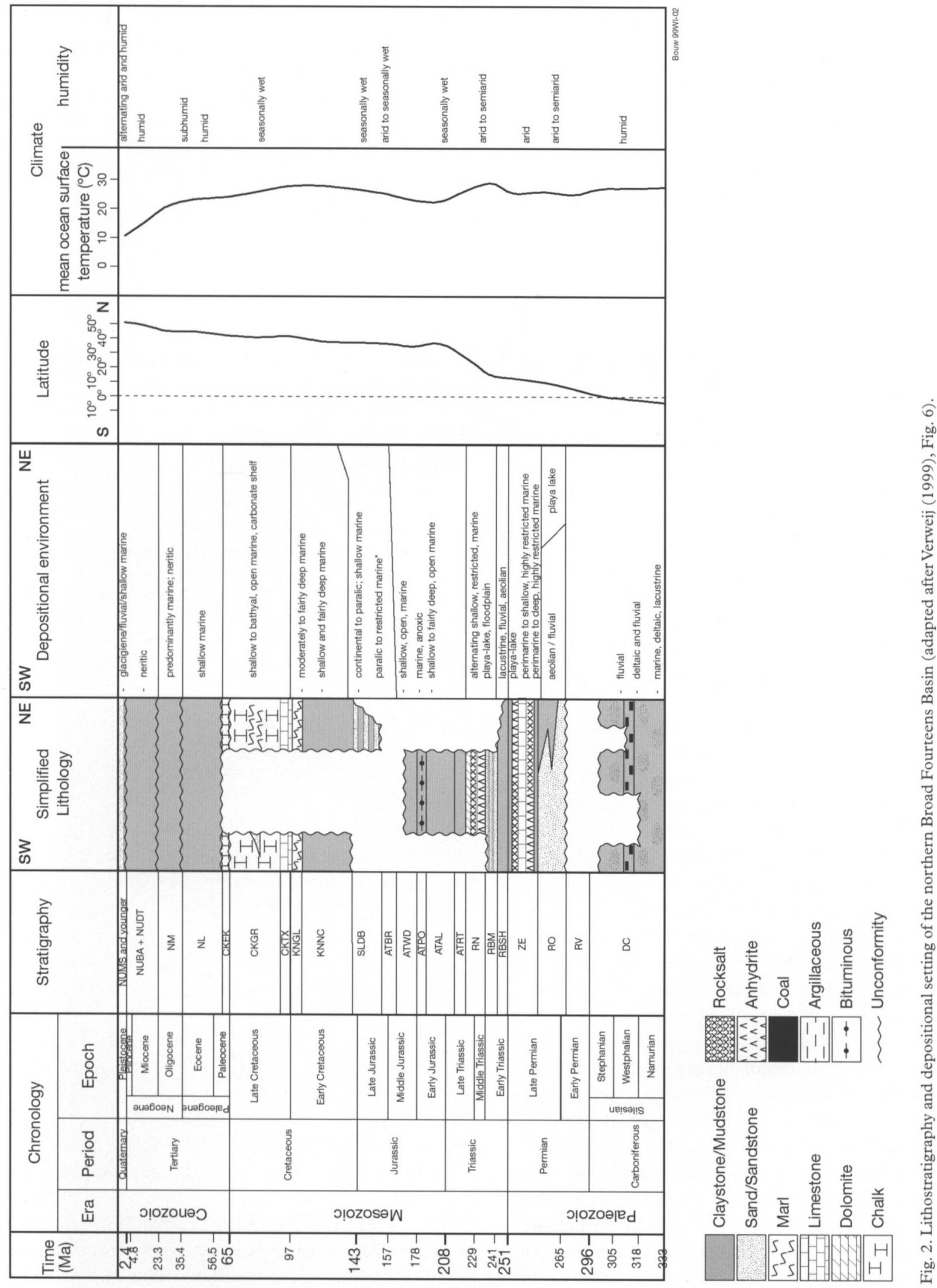

1989). At present these Rotliegend sandstones show a number of gas accumulations along the studied crosssection (Bouw, 1999). A marine transgression followed, and in a restricted marine setting 350 to 950 $\mathrm{m}$ of Zechstein evaporites were deposited. The highest sedimentation rates during the Carboniferous to recent history of the northern Broad Fourteens Basin occurred during deposition of the Zechstein Z2 


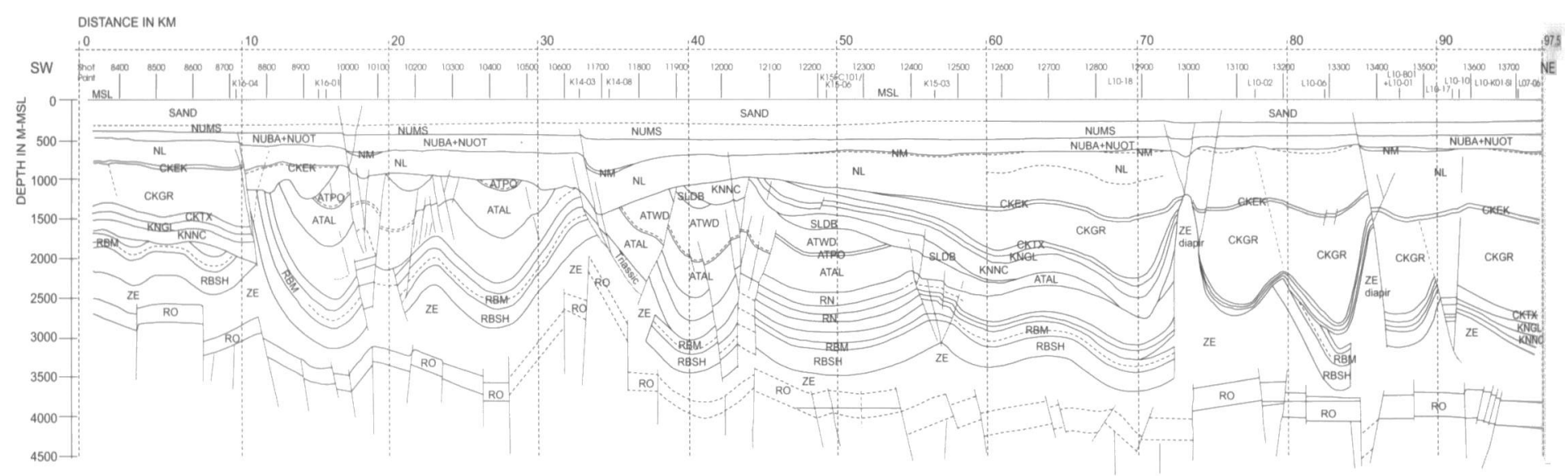

Fig. 3. Geological cross-section of the northern Broad Fourteens Basin, after seismic section SNST 83-04 and well-log data (Bouw, 1999). Location of cross-section is indicated in Fig. 1.

(Stassfurt Fm.) and Z3 (Leine Fm.) evaporites, with average sedimentation rates of $30-300 \mathrm{~m} / \mathrm{My}$. The low-permeability Zechstein Group is sealing presentday gas accumulations in the Upper Rotliegend reservoir rocks. The Zechstein Group plays an important role in the hydrogeological evolution of the northern Broad Fourteens area, because of salt movements and the effects of dissolution of evaporites on basin fluid composition. The first salt movements occurred during the Early Triassic Hardegsen phase (Remmelts, 1996).

In the Triassic a sequence of claystones, sandstones, and evaporites with uniform thickness was laid down. The sandstone members of the Triassic Main Buntsandstein Subgroup have a present-day porosity of about $10 \%$ and permeability of $1 \cdot 10^{-8}$ to $5 \cdot 10^{-7} \mathrm{~m} / \mathrm{s}$ (Roos \& Smits, 1983; Dronkers \& Mrozek, 1991; Purvis \& Okkerman, 1996; Spain \& Conrad, 1997). At the end of the Triassic and during the Jurassic, the Mesozoic Broad Fourteens Basin was formed by rifting and deposition of claystones of the Altena Group. The Late Kimmerian I phase in the Late Jurassic resulted in the erosion of about $700 \mathrm{~m}$ of the top of the Altena Group at the platform areas, and only local erosion of minor amounts of basin sediments. Most salt structures started to form diapirs during the Late Kimmerian I phase (Remmelts, 1996). Most likely, the Late Jurassic Breeveertien Fm. of the Schieland Group has been deposited with considerable thickness in the basin centre, but subsequently it was almost completely eroded during the Late Kimmerian II phase. Remnants of this formation are found at the north-east gradual transition from basin to platform area. The Late Kimmerian II phase, represented by the base Vlieland Claystone $\mathrm{Fm}$. unconformity, induced more than $600 \mathrm{~m}$ of erosion of the basin fill, along the studied cross-section (Bouw, 1999). At the same time significantly more

\section{Legend to Figs 2, $3 \& 4$}

DC: Limburg Group, Upper Carboniferous

RV: $\quad$ Lower Rotliegend Group

RO: Upper Rotliegend Group, Late Permian

ZE: Zechstein Group, Late Permian

RB: Lower Germanic Trias Group, Lower Triassic RBSH: Lower Buntsandstein Fm. RBM: Main Buntsandstein Subgroup

RN: Upper Germanic Trias Group, Middle and Upper Triassic

AT: Altena Group, Jurassic ATRT: Sleen Fm. ATAL: Aalburg Fm. ATPO: Posidonia Shale Fm ATWD: Werkendam Fm. ATBR: Brabant Fm.

SL: Schieland Group, Late Jurassic - Early Cretaceous SLDB: Breeveertien Fm.

KN: Rijnland Group, Cretaceous KNNC:Vlieland Claystone Fm. KNGL: Holland Fm.

CK: Chalk Group, Cretaceous and Danian CKTX: Texel Fm. CKGR: Ommelanden Fm. CKEK: Ekofisk Fm.

NL: Lower North Sea Group, Tertiary

NM: Middle North Sea Group, Tertiary

NU: Upper North Sea Group, Tertiary and Quaternary NUBA: Breda Fm. NUOT: Oosterhout Fm. NUMS: Maassluis Fm.

erosion occurred at the north-east platform area than at the south-west platform area, with estimated erosional thicknesses of more than $1,000 \mathrm{~m}$ and about $450 \mathrm{~m}$, respectively. In contrast to the southern Broad Fourteens Basin, the Early Cretaceous Vlieland Sandstone Fm. was not deposited in the northern Broad Fourteens Basin. During the Valanginian, the marginal highs, the Winterton High and Texel-IJsselmeer 
High permeability
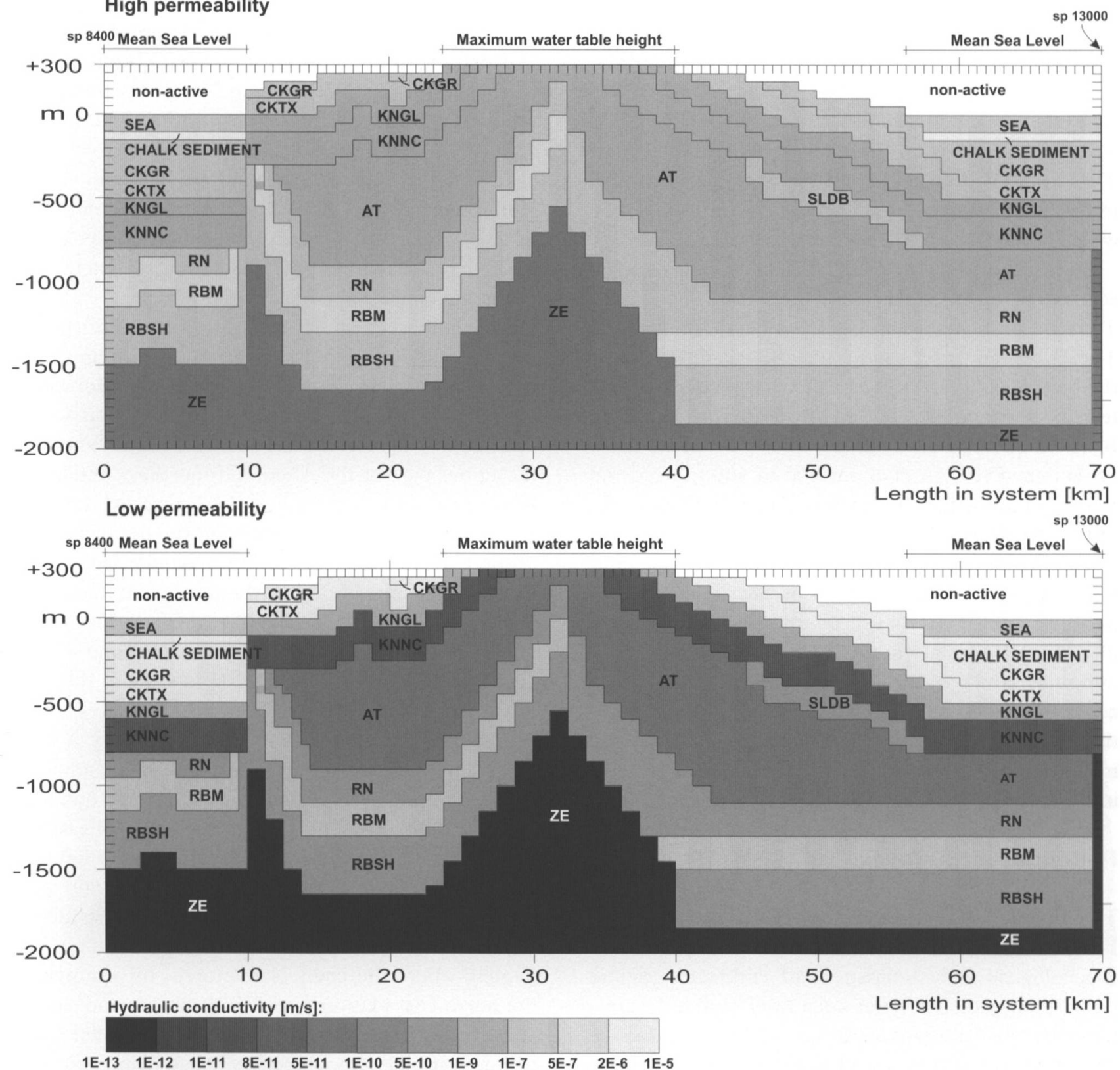

Fig. 4. Late Cretaceous model geometry of the northern Broad Fourteens Basin: high and low permeability scenarios.

High (Fig. 1), were uplifted, and the Upper Rotliegend Group was exposed on these highs.

During the Late Cretaceous 500 to $1,300 \mathrm{~m}$ of pelagic carbonates of the Ommelanden Fm. were deposited on the platform areas, along the cross-section (Bouw, 1999). It seems that only about $100 \mathrm{~m}$ of Ommelanden chalk accumulated in the basin centre, prior to inversion. This can be deduced from the thickness of chalk on the south-west platform before it shows inversion-related marly and sandy intercalations, assuming a uniform pre-inversion thickness distribution in the area. Present-day thickness of the Ommelanden Fm. is far from uniform, due to effects of salt tectonics and basin inversion. The Cretaceous Ommelanden Fm. consists of mainly chalk with local- ly minor amounts of marl and sand. Present-day porosity of the chalk is $10-30 \%$ at a depth of $1,000 \mathrm{~m}$; present-day permeability is generally low, about $1 \cdot 10^{-7} \mathrm{~m} / \mathrm{s}$ (Price, 1987), but locally where fractured it can be very high, up to $1 \cdot 10^{-5} \mathrm{~m} / \mathrm{s}$ (Remmelts, 1996). Shortly after deposition, the nanno ooze (which by diagenesis is transformed into pelagic chalk at a depth of $150-300 \mathrm{~m}$ ) had porosities of $70-80 \%$, as based on a general porosity-depth relationship for pelagic chalk (Einsele, 1992). The Broad Fourteens Basin was inverted at the end of the Late Cretaceous and about 1,300 $\mathrm{m}$ (in the northern Broad Fourteens Basin, based on reconstruction) to $3,000 \mathrm{~m}$ (in the basin centre, after Huyghe \& Mugnier, 1994; Nalpas et al., 1995) of strata were eroded in the Broad Four- 
teens area. Growth of salt structures was enhanced during inversion (Remmelts, 1996) and this is represented by large thickness variations in the Ommelanden chalk at the north-east platform area. Inversion took place in five to seven pulses within about 20 My (seismic section, Huyghe \& Mugnier, 1994). These pulses are represented by erosional unconformities in the Ommelanden Fm. at the basin margins, where about 300 to $500 \mathrm{~m}$ of chalk was eroded.

After peneplanation of the Broad Fourteens area, subsidence of the North Sea Basin took place in the Tertiary and Quaternary, with only minor erosion. The Pyrenean uplift phase, which is represented by the base Middle North Sea Group unconformity, led to minor erosion of about 0 to $200 \mathrm{~m}$ in the northern Broad Fourteens area (Bouw, 1999), whereas more pronounced erosion of about 400 to $500 \mathrm{~m}$ occurred in the southern Broad Fourteens area (Nalpas et al., 1996). Salt movements were accelerated during this phase (Remmelts, 1996). During the Tertiary and Quaternary, a thick succession of claystones was deposited (about $500 \mathrm{~m}$ in the south-west and 1,300 $\mathrm{m}$ in the north-east along the cross-section) and about $300 \mathrm{~m}$ of sand was laid down at the top of the coarsening upward Quaternary strata (Fig. 3). Sedimentation rates during the Quaternary, about 170-200 $\mathrm{m} / \mathrm{My}$, were ten times higher than sedimentation rates in the Tertiary.

\section{Hydrogeological setting}

The hydrogeological setting of the northern Broad Fourteens Basin includes a description of (paleo-)hydrogeological characteristics of lithostratigraphic units, composition of interstitial fluids and a description of basin-scale geological structures that influence fluid flow, including an estimated paleotopography. These hydrogeological data were used to construct our model scenarios for fluid flow during Late Cretaceous inversion. In addition, we give a brief overview of meteoric water infiltration phases in the northern Broad Fourteens area.

Present-day hydrogeological characteristics of lithostratigraphic units

For this study, the lithostratigraphic units of the northern Broad Fourteens Basin area have been assigned a basin-scale lithology based on well-log data (Bouw, 1999). For modelling purposes, lithostratigraphic units were grouped into hydrogeological units, with common lithology, porosity and permeability (see Table 1). For abbreviations of units, see the legend to Figs 2, $3 \& 4$. Below we discuss general hydrogeological characteristics of lithostratigraphic units and classification of lithostratigraphic units into hydrostratigraphic units (aquifer versus aquitard, and dual character i.e. locally an aquifer and regionally an aquitard), based on lithology, porosity and permeability data derived from Bouw (1999).

At present, important aquifers are the Upper Rotliegend Group, the Main Buntsandstein Subgroup, and the Quaternary sands. The Upper Rotliegend Group and the Main Buntsandstein Subgroup are expected to have had similar or even higher permeabilities shortly after deposition and during inversion. Important aquitards are the Zechstein Group that increases in thickness towards the north-east platform, the Lower Buntsandstein Fm. and Upper Germanic Trias Group, the Altena Group (except for the upper part of the Altena Group that contains an increasing sand percentage), the Lower, Middle and Upper North Sea Groups (except for the upper part of the Upper North Sea Group, since the Quaternary strata are coarsening upward and contain about 300 $\mathrm{m}$ of sand at the top). The Breeveertien Fm. of the Late Jurassic - Early Cretaceous Schieland Group contains sandlenses, although the dominant lithology is claystone. The Breeveertien Fm. is therefore expected to have a large anisotropy: vertically it is an aquitard, horizontally it may be a low quality aquifer.

The Chalk Group displays a dual character with respect to fluid flow. On a regional scale, the Chalk Group can be regarded as an aquitard with low matrix permeability, because of small pores and pore throats in the chalk (Price, 1987), and later reduction of permeability by diagenesis. Locally it is an aquifer, namely where the chalk is fractured, for example at the north-east platform above salt domes and salt diapirs. In horizontal sense it is locally an aquifer at the south-west platform where a wedge of sandy layers is present within the chalk. Before the chalk-limestone transition at a depth up to about 500-1,000 m, the Chalk Group may have been a regional aquifer with much higher porosity and permeability than at present-day. Also during inversion the Chalk Group may have been an aquifer due to fracturing and karstification at the exposed surface. On the other hand, chalk undergoes rapid lithification when exposed to freshwater circulation (Einsele, 1992), which may have occurred during inversion.

\section{Present-day salinity of interstitial fluids}

Interstitial fluid salinities vary greatly in the North Sea area, but reach in general highest values in the southern and central North Sea where they can exceed halite saturation values, namely $250,000 \mathrm{ppm}$ 
(Warren \& Smalley, 1993). The distribution and diapirism of Zechstein salts mainly control the salinity distribution in the southern North Sea. The highest salinity distribution closely follows the distribution of the Zechstein Z3 polyhalite (Warren \& Smalley, 1993). In the southern North Sea, a pronounced salinity increase is found in the $500 \mathrm{~m}$ of sediments just above the evaporites, where salinities approach halite saturation values (Bjørlykke \& Gran, 1994). In the northern North Sea area, where underlying evaporites and salt diapirs are absent, salinities do not increase with depth. However, in areas where salt diapirs and underlying evaporites are present, for example the Central Graben area, wide ranges in salinities can be found at the same depth, and a trend towards higher salinities with increasing depth can be seen (Bjørlykke \& Gran, 1994). In the Central Graben, the salinity is up to $300,000 \mathrm{ppm} \mathrm{NaCl}$ equivalent at 3,000 $\mathrm{m}$ depth. The salinity distribution in the Broad Fourteens area is expected to be analogous to other areas where salt diapirs and underlying evaporites are present. In the Broad Fourteens area, we expect a scatter in salinities due to salt diapirism and a trend to increasing salinities with depth, with salinities approaching halite saturation in the $500 \mathrm{~m}$ of section closest to the evaporites.

In the northern Broad Fourteens Basin, presentday fluid resistivity is $0-0.1 \Omega \mathrm{m}$, corresponding to total dissolved solids (TDS) of equal to or greater than $100,000 \mathrm{ppm}$. In comparison, present-day fluid resistivity in the southern Broad Fourteens Basin is 0.1 $0.3 \Omega \mathrm{m}$, corresponding to TDS equal to $30,000-$ $100,000 \mathrm{ppm}$. A clear distinction is visible between areas where (thick) Zechstein evaporites are present and areas where Zechstein evaporites are absent. The indicated values for northern and southern Broad Fourteens Basin are for the combined resistivity values of the Paleocene, Middle Jurassic and Rotliegend interstitial fluids, after Warren \& Smalley (1993).

Both the Zechstein Group and Upper Germanic Trias Group are expected to highly influence the fluid composition in the northern Broad Fourteens Basin by dissolution of evaporites, and subsequent diffusion and density-driven flow of saline fluids. The Zechstein Group may not only have increased the salinity of interstitial fluids in the northern Broad Fourteens Basin within $500 \mathrm{~m}$ above the top of the Zechstein evaporites, but it may also have increased the salinity of fluids in strata below the Zechstein evaporites: the Upper Rotliegend Group and possibly the top of the Limburg Group. Fluid salinities and densities within the Zechstein Group itself may be very high. Sullivan and co-workers (1994) published results of analysis of Zechstein formation fluids of the Leman Field, UK block 49/26, southern North Sea. These fluids have TDS of $411,280 \mathrm{mg} / 1$, density of $1,290 \mathrm{~kg} / \mathrm{m}^{3}$ and fluid resisitivity of $0.0516 \Omega \mathrm{m}$ at $19^{\circ} \mathrm{C}$. Fluid salinities within the Zechstein Group in the northern Broad Fourteens are expected to reach similar TDS values.

\section{Basin-scale geological structures that influence fluid flow}

The Broad Fourteens Basin is an approximately 45 $\mathrm{km}$ wide, asymmetric basin. The south-west edge of the Broad Fourteens Basin is formed by a major graben boundary fault. In the north-east exists a gradual transition between basin and platform (Fig. 3). The asymmetrical character of the basin will influence fluid flow on a basin-scale. Apart from the asymmetrical character of the basin perpendicular to the basin axis, the Broad Fourteens Basin shows important lateral variation along the basin axis. Since this study is based on a $2 \mathrm{D}$ section, the $3 \mathrm{D}$-variation is not discussed in detail. For more details about 3D variation in Zechstein evaporite distribution and structural elements, we refer to the work of Nalpas and co-authors $(1995,1996)$ who present a 3D seismic study of the northern Broad Fourteens Basin. The Zechstein Group is a very important aquitard and it highly influences the fluid composition of the northern Broad Fourteens Basin due to dissolution of Zechstein evaporites. It is also expected to influence fluid flow direction, due to its diapirism, its low permeability and due to the higher densities of saline fluids. The thickness of the Zechstein Group, and therefore the influence of the Zechstein Group on fluid flow, both by aquitard behaviour and by density-driven flow of saline fluids, increases towards the northern part of the Broad Fourteens area.

The following structures are expected to have a pronounced influence on fluid flow in the study area.

- The most likely sealing graben fault that forms the south-west boundary of the northern Broad Fourteens Basin, which can be seen around Shot Point 8,700 of seismic section SNST 83-04 (Fig. 3). Its present-day sealing character is inferred from the smearing of Zechstein evaporites along the fault plane. The fault is expected to have influenced fluid flow direction throughout basin evolution, but its permeability may have changed significantly during basin evolution.

- The inverted basin centre where the Zechstein Group is uplifted above its regional level, around Shot Point 11,700 (Fig. 3). The uplifted Zechstein will generate thermohaline flow of saline fluids towards adjacent parts of the basin.

- The Zechstein diapirs along the cross-section, namely the north-south trending and about $35 \mathrm{~km}$ 
long diapir at Shot Point 13,000 (Fig. 3), and the north-west south-east trending and about $20 \mathrm{~km}$ long diapir at Shot Point 13,400 (Fig. 3). These diapirs will influence fluid flow direction and salinities in surrounding strata and they will generate thermohaline flow.

- A number of major basement faults, with displacements sometimes exceeding the thickness of the Upper Rotliegend Group, which is about 200-340 $\mathrm{m}$. These faults juxtapose the Upper Rotliegend Group against the Zechstein Group. Faults with displacement exceeding half the thickness of the Upper Rotliegend Group have over $80 \%$ chance of sealing (Knott, 1993). At least thirteen faults with $>80 \%$ chance of sealing, are encountered in the Upper Rotliegend within the $90 \mathrm{~km}$ long cross-section through the northern Broad Fourteens Basin and adjacent platforms (Fig. 3).

The main structural elements (namely the graben boundary fault, the uplifted Zechstein Group in the basin centre, and the diapir at Shot Point 13,000), are incorporated in our simplified basin-scale geometry for fluid flow modelling. Our model represents the geometry at the last stage of inversion before peneplanation, and we assume that the uplifted Zechstein in the basin centre and the diapir were fully developed at this timing. The Upper Rotliegend Group and the sealing faults in the Rotliegend are not included in our model, because the freshwater lens is not expected to have fully penetrated the Zechstein Group. The model geometry therefore extends vertically from the top of the palaeo-topography into the Zechstein Group. The model geometry extends laterally from the south-west platform area at the left-hand side to the diapir at Shot Point 13,000 at the right-hand side. An estimate of topographic elevation above mean sea level during Late Cretaceous basin inversion can be used to give a constraint for our numerical model scenarios. Therefore, we reconstructed Late Cretaceous topography based on an analysis of uplift versus denudation rates. We assume Late Cretaceous inversion had the following characteristics: 1 . the duration of the inversion period was 16 to $20 \mathrm{My} ; 2$. a time lag of $3 \mathrm{My}$ may have occurred before denudation became effective, based on general denudation data (Einsele, 1992); and 3. the total basin uplift was 1,300 to 3,000 $\mathrm{m}$. Assuming the denudation rate balanced the uplift rate after the $3 \mathrm{My}$ time lag, a minimum elevation of 200 to $600 \mathrm{~m}$ above mean sea level may have been reached in the uplifted basin centre. Assuming a constant uplift rate of about $65 \mathrm{~m} / \mathrm{My}$ (a conservative estimate, based on a total uplift of $1,300 \mathrm{~m}$ and total inversion time of $20 \mathrm{My}$ ), and taking into account the humid temperate climate which prevailed during the Late Cretaceous, the maximum equilibrium elevation that can be reached in a large area, by a balance between uplift and denudation rates is about 750 to $1,000 \mathrm{~m}$ (Einsele, 1992). The Late Cretaceous topography is therefore assumed to be $200-300 \mathrm{~m}$ above mean sea level, as a conservative estimate.

\section{Meteoric water infiltration in the northern Broad Four- teens Basin}

Tectonic phases are expected to have had a profound influence on the fluid composition, fluid pressure, and geothermal evolution of the northern Broad Fourteens Basin. In this study, we focus on the Late Cretaceous basin geometry and the hydrodynamic evolution shortly after this important inversion phase. For completeness, we give an overview of tectonic phases and timing of events that may have led to important meteoric water infiltration in the northern Broad Fourteens area:

- Late Variscan phase: erosion of Limburg Group;

- Late Kimmerian I phase: uplift and erosion of platforms, represented by the base Breeveertien Fm. unconformity, timing about $150 \mathrm{My}$ ago (Bouw, 1999);

- Late Kimmerian II phase: erosion of Triassic strata in basin centre, represented by the base Vlieland Claystone Fm. unconformity, timing about $140 \mathrm{My}$ ago (Bouw, 1999);

- Exposure of the Upper Rotliegend Group at the Winterton High, $130 \mathrm{My}$ ago (Lee et al., 1989);

- Exposure of the Upper Rotliegend Group at the Texel-IJsselmeer High, 120-105 My ago (Lee et al., 1989);

- Late Cretaceous Sub-Hercynian inversion in the Turonian to Maastrichtian (Huyghe \& Mugnier, 1994), about 89-67 My ago, erosion of basin centre and minor erosion of adjacent platform areas.

Verweij et al. (2000, 2002) have presented results of $2 \mathrm{D}$ basin modelling of the southern Broad Fourteens Basin and show that the observed biodegradation and water-washed nature of Q1 oil reservoirs (Roelofsen \& De Boer, 1991) is consistent with topography-driven meteoric water flow during Late Cretaceous inversion. These Early Cretaceous oil reservoirs of the Vlieland Sandstone Fm. are at present-day depths of about 1,250 to $1,350 \mathrm{~m}$ (Roelofsen \& De Boer, 1991). According to Roelofsen \& De Boer (1991) the timing of oil emplacement is about 80 to $60 \mathrm{My}$ ago. Roelofsen \& De Boer (1991) show that degradation of oil reservoirs increases towards the axis of the Broad Fourteens Basin. This may indicate that the 
amount of meteoric water flow increased towards the centre of the basin. The Vlieland Sandstone Fm. is not present in the northern Broad Fourteens area. Nevertheless, the degradation of oil in the southern Broad Fourteens Basin indicates that meteoric water infiltration may also have occurred during inversion of the northern Broad Fourteens Basin.

\section{Numerical model description}

In order to constrain the extension of topography-driven meteoric water flow in the northern Broad Fourteens Basin during the Late Cretaceous inversion, a density-dependent fluid flow model is constructed in this study with the numerical modelling package MOCDENS3D (Oude Essink, 1999, 2001). The computer code is based on the three-dimensional computer code MOC3D (Konikow et al., 1996), which is adapted for fluid density differences. The fluid flow equation is solved by the so-called MODFLOW module (McDonald \& Harbaugh, 1988; Harbaugh \& McDonald, 1996). The advection-dispersion equation, which simulates the solute transport, is solved by the MOC module using the method of characteristics (Konikow et al., 1996). In this method, advective transport of solutes is modelled by means of the method of particle tracking and dispersive transport by means of the finite difference method. MOCDENS3D takes into account hydrodynamic dispersion (the combination of mechanical dispersion and molecular diffusion), expressed through the conventional notation:

$$
D_{i j}=\left(D_{m}+\alpha_{T}|V|\right) \delta_{i j}+\left(\alpha_{L}-\alpha_{T}\right) \frac{V_{i} V_{j}}{|V|}
$$

where $D_{i j}$ is the coefficient of hydrodynamic dispersion $\left[\mathrm{L}^{2} \mathrm{~T}^{-1}\right], D_{m}$ is the coefficient of molecular diffusion $\left[\mathrm{L}^{2} \mathrm{~T}^{-1}\right], \alpha_{L}$ is the longitudinal dispersivity of the aquifer $[\mathrm{L}], \alpha_{T}$ is the transversal dispersivity of the aquifer [L], $V_{i}$ and $V_{j}$ are the components of the effective velocity in the $i$ and $j$ directions respectively [L $\left.\mathrm{T}^{-1}\right],|V|$ is the magnitude of the effective velocity [L $\left.\mathrm{T}^{-1}\right]$, and $\delta_{i j}=1$ if $i=j$ and $\delta_{i j}=0$ if $i \neq j$. Mechanical dispersion is caused by velocity variations at the microscopic scale. The spreading depends on both fluid flow and the characteristics of the pore system through which the flow takes place. Molecular diffusion is caused by random movement of molecules in a fluid and depends on the concentration gradients, the properties of the fluid and the soil. The molecular diffusion for a conservative solute as chloride in a porous medium is approximately $10^{-9} \mathrm{~m}^{2} / \mathrm{s}$ (De Marsily, 1986). The freshwater head $\phi_{f}$, which is introduced to take into account differences in density in the calculation of the head, is defined as:

$$
\phi_{f}=\frac{P}{\rho_{f} g}+z
$$

where $\phi_{f}$ is the freshwater head [L], $P$ is the pressure $\left[\mathrm{M} \mathrm{L}^{-1} \mathrm{~T}^{-2}\right], \rho_{f}$ is the reference density $\left[\mathrm{M} \mathrm{L}^{-3}\right]$, usually the density of fresh groundwater (without dissolved solids) at mean subsoil temperature, $g$ is the gravity acceleration $\left[\mathrm{LT}^{-2}\right]$, and $z$ is the elevation head $[\mathrm{L}]$. A linear equation of state couples groundwater flow and solute transport:

$$
\rho(C)=\rho_{f} L+\beta_{C}\left(C-C_{0}\right)_{-}
$$

where $\rho(C)$ is the density of groundwater $\left[\mathrm{M} \mathrm{L}^{-3}\right], C$ is the chloride concentration $\left[\mathrm{M} \mathrm{L}^{-3}\right], \beta_{C}$ is the volumetric concentration expansion gradient $\left[\mathrm{L}^{3} \mathrm{M}^{-1}\right]$, and $C_{0}$ is the reference chloride concentration $[\mathrm{M}$ $\left.\mathrm{L}^{-3}\right]$. The volumetric concentration expansion gradient $\beta_{C}$ is $1.34 \cdot 10^{-6} \mathrm{1} / \mathrm{mg} \mathrm{Cl}^{-}$.

The vertical Darcian velocity (specific discharge) now also takes into account a so-called buoyancy term to consider differences in density (Oude Essink, 2001).

In general, thermohaline flow needs to be considered when evaporites are present in the model domain, because of fluid density effects caused by both high thermal conductivity and dissolution of evaporites. In the case of the northern Broad Fourteens Basin, thermal effects can most likely be neglected, and only density effects due to dissolution of evaporites are taken into account. Temperature effects on fluid density are counteracted by a moderate background salinity increase with depth of $>25,000$ $\mathrm{ppm} / \mathrm{km}$ (Bjørlykke \& Gran, 1994), while drill stem tests of wells L10-06, L10-10 and L08-02 at the north-east platform adjacent to the Broad Fourteens area show much higher gradients (Bouw, 1999). Temperature effects on density-driven flow were also neglected because of a lack of reliable data on temperature and salinity gradients in the basin centre and thermal conductivities of hydrogeological units.

The numerical model discretization is based on rectangular elements, with an estimated paleotopography of $200-300 \mathrm{~m}$. The timing at $\mathrm{t}=0 \mathrm{My}$ is at the end of inversion, when the post-inversion geometry of the basin is obtained (Fig. 4), and after an initial salinity distribution is generated (top left profiles in Figs. 5, $6 \& 7$ ). The simplified post-inversion geometry is derived from the present-day cross-section by removing all post-inversion sediments and extending the (now eroded) pre-inversion strata upwards until the assumed height of the paleotopography is reached. The model contains 112 by 46 elements, each $625 \mathrm{~m}$ long and $50 \mathrm{~m}$ high. The modelled cross- 
section is $70 \mathrm{~km}$ long and $2,300 \mathrm{~m}$ high. Each element contains initially nine particles to solve the advection term of the solute transport equation. As no basin-scale values for permeability are know from literature, we choose to model scenarios with best estimates within the range of expected values for permeability. Also, the paleotopography is only known within a range of expected values, therefore variations in water table are modelled to show the sensitivity of the model for variations in head and permeability. Three different scenarios with variations in water table head and permeability are modelled with MOCDENS3D:

- Model Bre1, high permeability, maximum water table head $275 \mathrm{~m}$;

- Model Bre2, high permeability, maximum water table head $137.5 \mathrm{~m}$;

- Model Bre3, low permeability, maximum water table head $275 \mathrm{~m}$.

Fig. 4 shows specific values for high and low permeability scenarios. For all model scenarios, we assume that the water table follows the ground surface, and the water table head varies along the cross-section as follows. The water table head is equal to mean sea level ( $0 \mathrm{~m} \mathrm{MSL})$ at the intervals $0-10.0 \mathrm{~km}$ and $56.25-70.0 \mathrm{~km}$. The water table head is maximal at the interval $23.75-40 \mathrm{~km}$ (Fig. 4). In between, the head decreases linear from maximal to mean sea level. See for exact head values the top left profiles at $t=0$ My in Figs 5, 6 \& 7.

Table 1 lists model characteristics and parameters based on literature and well-log data, such as lithology, porosity, hydraulic conductivity and anisotropy values. Note the two columns with different hydraulic conductivity values, namely one for the low permeability model and one for the high permeability models. The hydraulic conductivity values had to be ad- justed somewhat due to numerical convergence problems. Therefore they should not be used as actual values for hydrogeological units. Porosity values in Table 1 do not necessarily represent present-day values. For example, chalk porosities were adjusted to realistic values, which can be found shortly after nanno ooze deposition, based on a general porosity-depth relationship for pelagic carbonates, after Einsele (1992).

The total simulation time is $4 \mathrm{My}$, after $1 \mathrm{My}$ simulation time to obtain an initial salinity distribution. The flow time step to recalculate the groundwater flow equation equals 500 years. The convergence criterion of the head in the fluid flow equation is equal to $10^{-5} \mathrm{~m}$. The longitudinal dispersivity is set equal to $10 \mathrm{~m}$, while the ratio of transversal to longitudinal dispersivity is 0.1 . Based on element size and work of Gelhar and co-authors (1992), we assume that these values are reasonable.

\section{Model boundary conditions}

\section{Fluid composition}

The chloride concentration of infiltrating meteoric water is set to $100 \mathrm{mg} \mathrm{Cl} / \mathrm{l}$. The fluid composition of lithostratigraphic units is set initially to $18,630 \mathrm{mg}$ $\mathrm{Cl} / 1$ (equal to seawater composition), except for the Zechstein Group. The fluid composition of the Zechstein Group is set to a fixed concentration of 218,920 $\mathrm{mg} \mathrm{Cl} / 1$, which is equal to a brine with TDS of about $411,000 \mathrm{mg} / \mathrm{l})$. This is a reasonable value if we assume that the composition of Zechstein fluids in the northern Broad Fourteens area is similar to the composition of Zechstein fluids in the Leman Field. The salinity of fluids within the Zechstein Group can be this high, because they are surrounded by a matrix of easily dissolving evaporites. Unlike the fluid composition

Table 1. Model parameters.

\begin{tabular}{|c|c|c|c|c|c|c|c|}
\hline Hydrogeological unit & Code & Lithology & $\begin{array}{l}\text { Thickness } \\
\text { (m) }\end{array}$ & $\begin{array}{l}\text { Porosity } \\
(\%)\end{array}$ & $\begin{array}{l}\text { High K } \\
(\mathrm{m} / \mathrm{s})\end{array}$ & $\begin{array}{l}\text { Low K } \\
(\mathrm{m} / \mathrm{s})\end{array}$ & $\begin{array}{l}\text { Aniso- } \\
\text { tropy }\end{array}$ \\
\hline Chalk sediment & - & Nanno ooze & 30 & $70^{(1,2)}$ & $1 \cdot 10^{-5}$ & $1 \cdot 10^{-5}$ & 1.1 \\
\hline Chalk Group & CKGR & Chalk & $100-300$ & $65^{(2)}$ & $1 \cdot 10^{-7(5)}$ & $2 \cdot 10^{-6}$ & $1.1^{(5)}$ \\
\hline Texel Fm. & CKTX & Limestone and shale & 100 & $50^{(2)}$ & $1 \cdot 10^{-7}$ & $2 \cdot 10^{-6}$ & 1 \\
\hline Holland Fm. & KNGL & Marl & 100 & 30 & $1 \cdot 10^{-9(3)}$ & $1 \cdot 10^{-9}$ & 2 \\
\hline Vlieland Claystone Fm. & $\mathrm{KNNC}$ & Silty claystone & $200-500$ & 30 & $1 \cdot 10^{-9}$ & $1 \cdot 10^{-11}$ & 10 \\
\hline Breeveertien Fm. & SLDB & Sandy claystone & $200-400$ & $15-20$ & $1 \cdot 10^{-7}$ & $5 \cdot 10^{-10}$ & 100 \\
\hline Altena Group & $\mathrm{AT}$ & Claystone & $<950$ & $20^{(3)}$ & $1 \cdot 10^{-9}$ & $5 \cdot 10^{-11}$ & 10 \\
\hline U. Germanic Trias Group & $\mathrm{RN}$ & Clayst., limest., and salt & 250 & $5^{(4)}$ & $1 \cdot 10^{-7(4)}$ & $5 \cdot 10^{-10}$ & $50^{(4)}$ \\
\hline Main Buntsandst. Subgr. & $\mathrm{RBM}$ & Claystone and sandstone & 200 & $20^{(4)}$ & $5 \cdot 10^{-7(6,7)}$ & $1 \cdot 10^{-7}$ & 100 \\
\hline Lower Buntsandstein Fm. & $\mathrm{RBSH}$ & Silty claystone & 350 & $20^{(3)}$ & $1 \cdot 10^{-7(3)}$ & $5 \cdot 10^{-10}$ & 10 \\
\hline Zechstein Group & $\mathrm{ZE}$ & Salt, anh. and limest. & $>300$ & 2 & $8 \cdot 10^{-11(8)}$ & $1 \cdot 10^{-13}$ & 1.0 \\
\hline
\end{tabular}

${ }^{1}$ Cornford, $1994 ;{ }^{2}$ Einsele, $1992 ;{ }^{3}$ Beekman et al., $1989 ;{ }^{4}$ Spain \& Conrad, $1997 ;{ }^{5}$ Price, $1987 ;{ }^{6}$ Purvis \& Okkerman, $1996 ;{ }^{7}$ Dronkers \& Mrozek, $1991 ;{ }^{8}$ Tóth, 1995. 

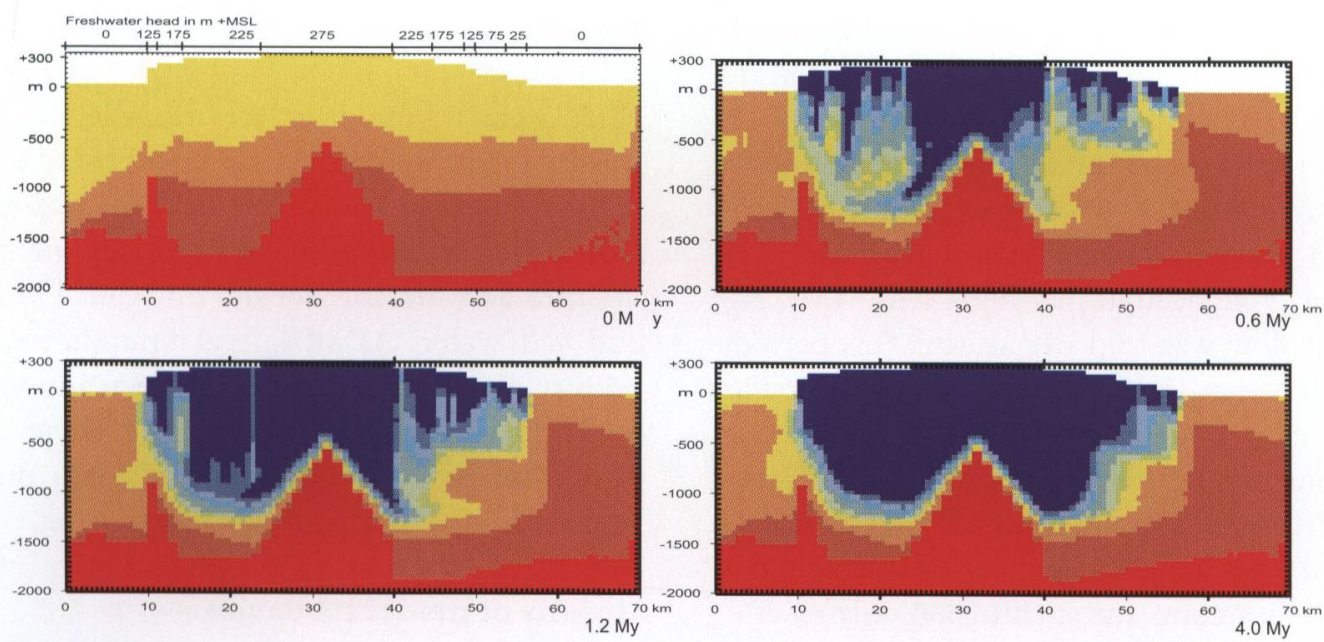

Fig. 5. Late Cretaceous basin-scale fluid flow in the northern Broad Fourteens Basin. Model scenario Brel (high permeability, high water table head of maximal $275 \mathrm{~m}$ ).
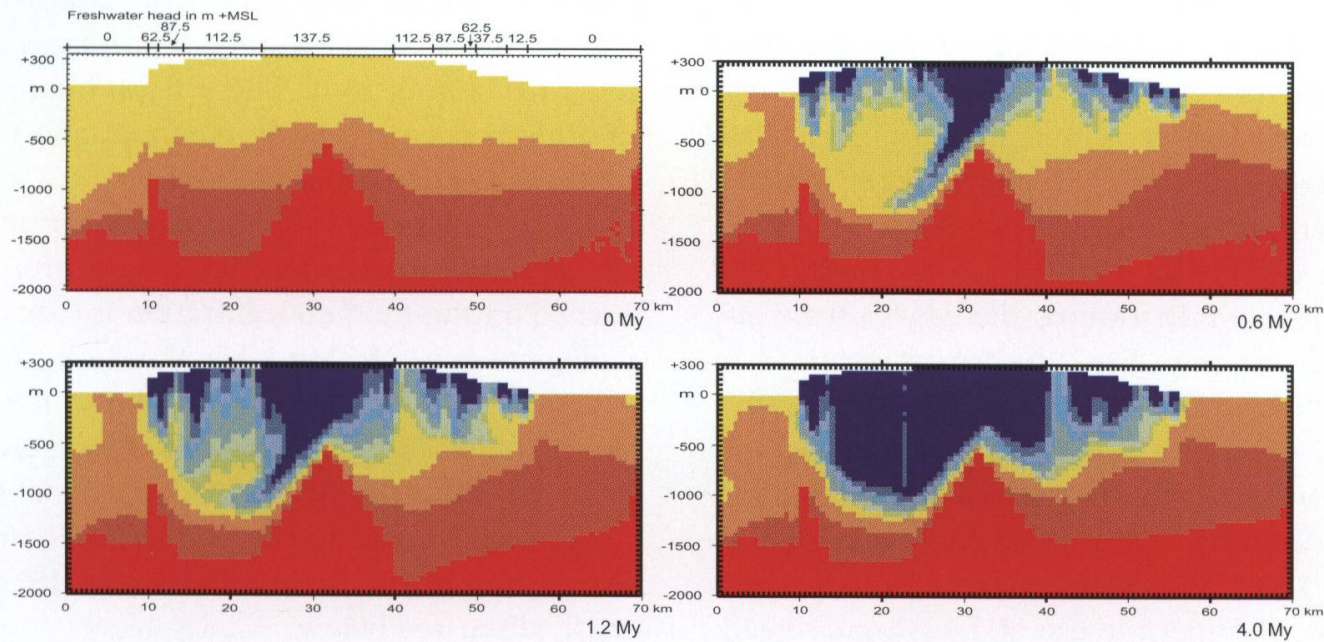

Fig. 6. Late Cretaceous basin-scale fluid flow in the northern Broad Fourteens Basin. Model scenario Bre2 (high permeability, low water table head of maximal $137.5 \mathrm{~m}$ )
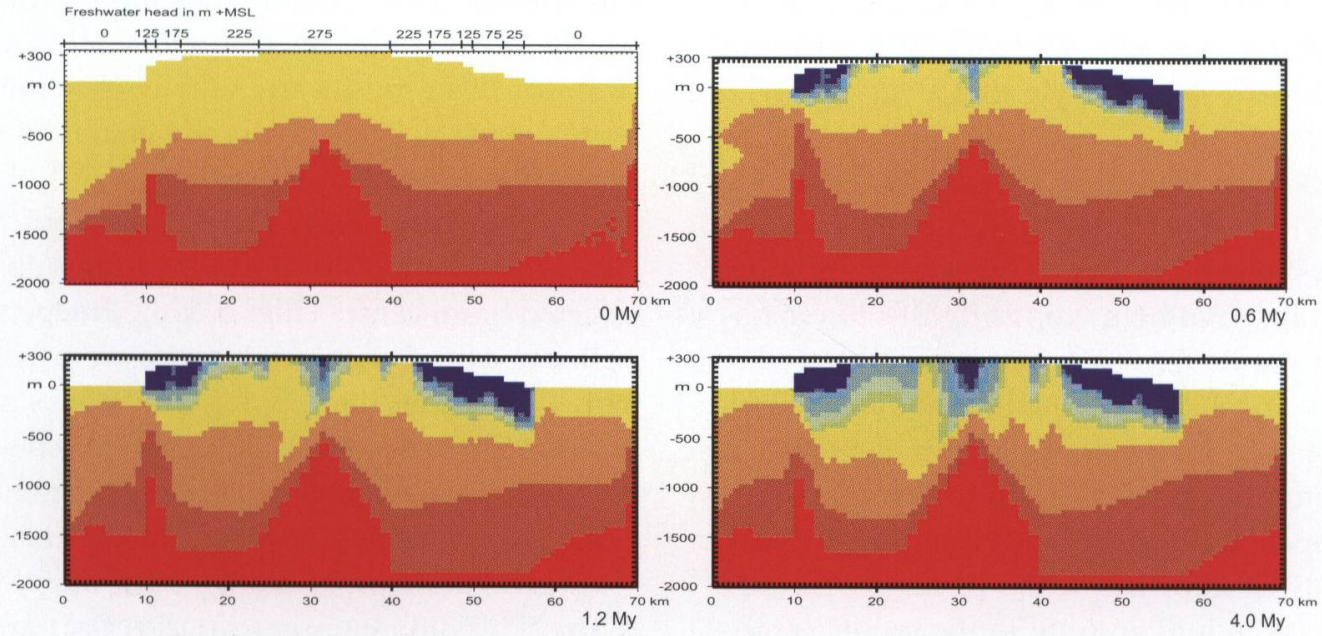

Fig. 7. Late Cretaceous basin-scale fluid flow in the northern Broad Fourteens Basin. Model scenario Bre3 (low permeability, high water table head of maximal $275 \mathrm{~m}$ ).

Legend for figures 5,6 and 7 .

Chloride concentration [mg/l]:

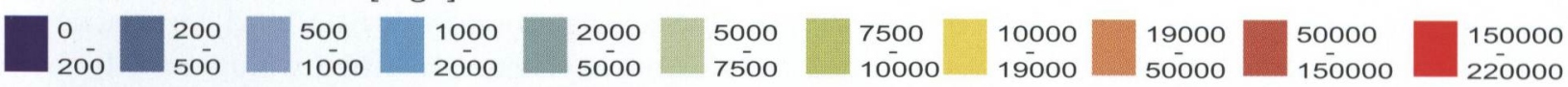


of other lithostratigraphic units, the fluid composition of the Zechstein Group remains fixed to brine throughout the total simulation time.

To take into account an initial salinity distribution by mixing of fluids due to molecular diffusion only, the model has been simulated for a period of $1 \mathrm{My}$ while the water table head at the top is $0 \mathrm{~m}$ MSL. No meteoric water flow was imposed during this period. After this initial simulation time of $1 \mathrm{My}$, molecular diffusion has caused an increase in salinity of the lithostratigraphic units directly above the Zechstein Group (top left profiles in Figs 5, $6 \& 7$ ). The actual simulation of meteoric water flow starts after this period of $1 \mathrm{My}$ with mixing due to diffusion only.

\section{Upper model boundary}

The elements above the model topography are confined, to increase the stability of the numerical model. The meteoric water inflow is modelled through a constant freshwater head along the entire upper boundary of the inverted basin. In scenarios Bre 1 and Bre 3 the freshwater head is set to $275 \mathrm{~m}$ in the basin centre, it declines smoothly towards the edges of the inverted basin. In scenario Bre2 the freshwater head is set to $137.5 \mathrm{~m}$ in the centre, again it declines smoothly towards the edges. An upper flux boundary is not considered to be an appropriate alternative, because it is unrealistic to force a flux into low-permeability strata and the Late Cretaceous effective rainfall is not well known. We consider the use of a freshwater head more appropriate than the use of an assumed value for effective rainfall, because the freshwater head is based on a more reliable assumption of the elevation of the ground surface, and meteoric water is not forced to enter the low permeable strata.

\section{Lower model boundary}

The lower no-flow boundary is chosen within the Zechstein Group. Arguments to justify this lower noflow condition are: 1 . Zechstein salt has a low permeability; 2 . its permeability is most likely unaffected by faulting due to its plasticity; and 3. the Zechstein Group is continuously present along the cross-section. The Upper Rotliegend and Limburg Group, stratigraphically situated below the Zechstein Group, have not been taken into account in the model geometry. We expect that they were not affected by the development of a freshwater lens. Instead, the Zechstein Group has been 'extended' downwards to get a rectangular lower model boundary, as this is a prerequisite for the numerical model.

\section{Lateral boundaries}

The lateral boundaries are modelled as hydrostatic pressure boundaries. At sea level (model depth $=0$ $\mathrm{m}$ ) the so-called freshwater head is chosen to be $0 \mathrm{~m}$ MSL. The freshwater head increases with depth, taking into account the density difference between fresh and salt water. At all lateral boundaries, the initial salinity distribution is used to determine the freshwater head. For instance, along the lower part of the right-hand side boundary, a Zechstein diapir is present with a fixed brine fluid composition.

\section{Results of model scenarios}

The results of model scenarios are sensitive to the chosen freshwater head and permeability values. Figs $5,6 \& 7$ give model results of scenarios Bre1, Bre2 and Bre3, respectively. These figures show the initial chloride concentration distribution, and the chloride concentration distribution after 0.6, 1.2 and 4.0 My. The initial chloride concentration distribution shows that the Zechstein evaporites have a pronounced influence on the fluid concentration in adjacent hydrogeological units. Within a few hundreds to more than a thousand metres vertically above the Zechstein Group, fluid salinity is increased. This increased salinity above evaporites was predicted by analogous situations in the North Sea area. The fluid concentration distribution of the three different model scenarios is briefly discussed below.

Model scenarios Bre1 and Bre2 (high permeability) both show the development of a 'freshwater' lens, which reaches the Zechstein Group in the basin centre. In the high permeability model scenarios, the contour of the freshwater lens is determined mainly by the geometry and hydraulic characteristics of the Main Buntsandstein Subgroup (RBM, Fig. 4) and the Altena Group (AT, Fig. 4). Meteoric water infiltrates the Main Buntsandstein Subgroup left of the inverted basin centre (Figs $5 \& 6$ ), independent of the freshwater head within the range we used. Both scenarios show that the dipping sandstones of the Main Buntsandstein Subgroup strongly channel fluid flow. Figs $5 \& 6$ show, after a simulation time of $4 \mathrm{My}$, a difference in salinity contours of the freshwater lens (blue area) at the right-hand side of the inverted basin centre. This difference in scenarios Bre 1 and Bre 2 can be explained by the fact that the permeability of the Altena and Upper Germanic Trias Groups is sufficiently low to prevent infiltration of water into the high permeability Main Buntsandstein Subgroup, if flow velocities and freshwater head are relatively low. Near steady state is reached within $1.5 \mathrm{My}$ for sce- 
nario Brel (high freshwater head) and within $4 \mathrm{My}$ for scenario Bre2 (low freshwater head). The fresh/salt water interface is located at a depth of about $1,200 \mathrm{~m}$ below mean sea level for scenario Brel and at 500 to $1,100 \mathrm{~m}$ for scenario Bre2.

Model scenario Bre3 (low permeability, high freshwater head) shows the development of a 'freshwater' lens with limited extent, which does not reach the Zechstein Group in the basin centre. The dipping sandstones of the Main Buntsandstein Subgroup have only a very limited influence on fluid flow (Fig. 7). Near steady state is reached within $3 \mathrm{My}$. In scenario Bre3, the fresh/salt water interface is located at a depth of about $200 \mathrm{~m}$ below mean sea level.

\section{Discussion}

The model results can be considered as possible scenarios, taking into account that the actual basin geometry was more complex. The model does not include faults that may be either sealing or channelling fluid flow in certain directions. It neglects effects of reactivation of faults during basin inversion, which could include changes in basin-scale permeability and promotion of fluid flow along certain pathways. We neglected presence and reactivation of faults, because of a lack of data on timing of reactivation, the exact position and permeability of these faults. We are aware that these features could affect the fluid flow in the basin to some extent.

It seems that the permeabilities of the Vlieland Claystone Fm., the Altena Group, and the Upper Germanic Trias Group are crucial to determine whether the sandstone of the Main Buntsandstein Subgroup could have been flushed during Late Cretaceous inversion. The permeability of the Vlieland Claystone Fm. and Altena Group is not well studied, permeability values of our model are estimates based on general values of claystone permeability. The results do indicate that flushing of the Main Buntsandstein Subgroup can be substantial when meteoric water reaches the sandstone. Flushing of the Main Buntsandstein Subgroup is possible, with an assumed hydraulic conductivity of $1 \cdot 10^{-9} \mathrm{~m} / \mathrm{s}$ for the Vlieland Claystone Fm. and Altena Group. Flushing of the Main Buntsandstein Subgroup no longer occurs, with an assumed hydraulic conductivity of $1 \cdot 10^{-11}$ and $5 \cdot 10^{-11} \mathrm{~m} / \mathrm{s}$ for the Vlieland Claystone $\mathrm{Fm}$. and Altena Group, respectively. Since the Altena Group is inverted, and therefore overcompacted, the hydraulic conductivity is expected to be low. The thickness of the low-permeability Vlieland Claystone Fm. and Altena Group is considerable, and therefore meteoric water cannot easily infiltrate.
Whether meteoric waters reaches the Zechstein Group in the basin centre during inversion also depends on the permeability of the Altena Group. This question is important, because meteoric water may have caused large amounts of subrosion of the Zechstein evaporites, and may have influenced the permeability of the Main Buntsandstein Subgroup by subsequent precipitation of dissolved minerals. During the Late Kimmerian II erosional phase, which is represented by the base Vlieland Claystone Fm. unconformity, significant parts of the Triassic strata were eroded in the basin and platform areas. Meteoric water flow through the Triassic strata must have been substantial during the period of Late Kimmerian II erosion. Isotopic analysis of diagenetic minerals in cores of the Main Buntsandstein Subgroup sandstones may give more constraints on the possible occurrence of meteoric water flushing during either the Late Kimmerian II phase or the Late Cretaceous inversion. Verweij \& Simmelink (2002) give an overview of all relevant geochemical data that support fluid flow events in the Broad Fourteens area, but at present we know no published data that support meteoric flushing of the Main Buntsandstein Subgroup. Another possibility to constrain the extension of the freshwater lens is to perform a basin-scale study of the permeability of the Altena Group. In addition, constructing a more complex basin geometry, which includes permeability of faults, should contribute to an increased reliability of the modelling results.

\section{Conclusions}

An important phase in the development of the Broad Fourteens Basin is the Late Cretaceous Sub-Hercynian inversion, with erosion in the northern Broad Fourteens area of $1,300-3,000 \mathrm{~m}$ in the basin centre, and $300-500 \mathrm{~m}$ at the basin margins, and the development of at least five, possibly seven, erosional unconformities in the Ommelanden Fm. at the southwest platform area. During basin inversion, a freshwater lens was most likely developed, as supported by the biodegraded and water-washed nature of oils in the southern Broad Fourteens Basin. A density-dependent fluid flow model of the northern Broad Fourteens Basin indicates that meteoric water infiltration could have reached and subroded the uplifted Zechstein salts in the basin centre. Near steady-state flow conditions are reached within 1.5 to $4 \mathrm{My}$. The model indicates that meteoric water could have flushed the sandstone of the Main Buntsandstein Subgroup if the hydraulic conductivity of the Rijnland and Altena Groups is equal to about $1 \cdot 10^{-9}$ to $1 \cdot 10^{-10} \mathrm{~m} / \mathrm{s}$, in general the highest values of hydraulic 
conductivity of claystones. Geochemical proof of meteoric water flushing through the Main Buntsandstein Subgroup or a study of basin-scale permeability of the Rijnland and Altena Groups is necessary to support the existence of a Late Cretaceous freshwater lens in the northern Broad Fourteens area. The numerical model results show that the influence of Zechstein evaporites on fluid composition in the northern Broad Fourteens Basin is pronounced. Model results show that fluid salinities are increased to a brine composition within a vertical distance of about $500 \mathrm{~m}$ of the Zechstein evaporites, as predicted from the analogy to salinity patterns in the Central Graben area. To constrain basin-scale hydrodynamic evolution, further research can be directed to basinscale permeability of the Altena Group, diagenetic minerals in the Main Buntsandstein Subgroup, or to present-day fluid composition of hydrogeological units in the Broad Fourteens area, compared to regional variation in fluid composition.

\section{Acknowledgements}

This publication is based on work carried out at TNO-NITG, under supervision of J.M. Verweij, H.J. Simmelink and R.T. van Balen, and their contribution is gratefully acknowledged. The thorough evaluation of and comments on this paper by the two reviewers are very much appreciated.

\section{References}

Beekman, H.E., Glasbergen, P., Slot, A.F.M. \& Prins, H.F., 1989. Inventarisatie en evaluatie van geohydrologische gegevens van Noordoost en Oost Nederland ten behoeve van het onderzoek naar de opberging van radioactief afval in zoutformaties. RIVM (Bilthoven, the Netherlands): $242 \mathrm{pp}$.

Biørlykke, K. \& Gran, K., 1994. Salinity variations in North Sea formation waters: implications for large-scale fluid movements. Marine and Petroleum Geology 11: 5-9.

Bouw, L., 1999. Geology, hydrogeology and hydrodynamics of the northern Broad Fourteens Basin, southern North Sea: a conceptual model. M. Sc. thesis, Department of Earth Sciences, Utrecht University \& Netherlands Institute of Applied Geoscience TNO - National Geological Survey (Utrecht, the Netherlands): $160 \mathrm{pp}$.

Cornford, C., 1994. Mandal-Ekofisk (!) Petroleum system in the Central Graben of the North Sea. In: Magoon, L.B. \& Dow, W.G. (eds): The petroleum system - from source to trap. AAPG Memoir 60: 537-571.

De Marsily, G., 1986. Quantitative Hydrogeology. Groundwater hydrology for Engineers. Academic Press, Inc. (Orlando, Florida): 440 pp.

Dronkers, A.J. \& Mrozek, F.J., 1991. Inverted basins of the Netherlands. First Break 9: 409-425.

Einsele, G., 1992. Sedimentary basins: evolution, facies and sediment budget. Springer-Verlag (Berlin, Germany): 628 pp.

Gelhar, L.W., Welty, C. \& Rehfeldt, K. R., 1992. A critical review of data on field-scale dispersion in aquifers. Water Resources Research 28: 1955-1974.

Harbaugh, A.W. \& McDonald, M.G., 1996. User's documentation for the U.S.G.S. modular finite-difference ground-water flow model. U.S.G.S. Open-File Report 96-485: 56 pp.

Huyghe, P. \& Mugnier, J.-L., 1994. Intra-plate stresses and basin inversion: A case from the Southern North Sea. In: Roure, F. (ed.): Peri-Tethyan Platforms. Edition Technip (Paris, France): 211-226.

Huyghe, P. \& Mugnier, J.-L., 1995. A comparison of inverted basins of the Southern North Sea and inverted structures of the external Alps. In: Buchanan, J.G. \& Buchanan, P.G. (eds): Basic Inversion. Geological Society Special Publication 88: 339-353.

Knott, S.D., 1993. Fault seal analysis in the North Sea. AAPG Bulletin 77: 778-792.

Konikow, L.F., Goode, D.J. \& Hornberger, G.Z., 1996. A three-dimensional method-of-characteristics solute-transport model (MOC3D). U.S.G.S. Water-Resources Investigations Report 964267: $87 \mathrm{pp}$.

Lee, M., Aronson, J.L., \& Savin, S.M., 1989. Timing and conditions of Permian Rotliegende sandstone diagenesis, southern North Sea: K/Ar and oxygen isotopic data. AAPG Bulletin 73: 195-215.

McDonald, M.G. \& Harbraugh, A.W., 1988. A modular three-dimensional finite difference groundwater flow model. U.S.G.S. Techniques of Water-Resources Investigations, Book 6, Chapter A1, $586 \mathrm{pp}$.

Nalpas, Th., Le Douaran, S., Brun, J.-P., Unternehr, P. \& Richert, J.-P., 1995. Inversion of the Broad Fourteens Basin (offshore Netherlands), a small-scale model investigation. Sedimentary Geology 95: 237-250.

Nalpas, Th., Richert, J.-P., Mulder, T. \& Unternehr, P., 1996. Inversion du 'Broad Fourteens Basin' ou Graben de la Haye (sud de la mer du Nord) - Apports de la sismique 3D. Bulletin des Centres Recherches Exploration-Production Elf Aquitaine 20: 309-321.

Nopec, 1988. North Sea Atlas, A structural encyclopaedia. Seismic atlas 3: section 91 .

Oude Essink, G.H.P., 1999. Simulating 3D density-dependent groundwater flow: the adapted MOC3D. In: De Breuck, W. \& Walschot, L (eds): Proceedings of the $15^{\text {th }}$ Salt Water Intrusion Meeting. Natuur- en Genceskundig Vennootschap (Ghent, Belgium): 69-79.

Oude Essink, G.H.P., 2001. Salt water intrusion in a three-dimensional groundwater system in the Netherlands: A numerical study. Transport in Porous Media 43: 137-158.

Price, M., 1987. Fluid flow in the Chalk of England. In: Goff, J.C. \& Williams, B.P.J. (eds): Fluid flow in sedimentary basins and aquifers. Geological Society Special Publication 34: 141-156.

Purvis, K. \& Okkerman, J.A., 1996. Inversion of reservoir quality by early diagenesis: an example from the Triassic Buntsandstein, offshore the Netheriands. In: Rondeel, H.E., Batjes, D.A.J. \& Nieuwenhuijs, W.H. (eds): Geology of gas and oil under the Netherlands. Kluwer Academic Publishers (Dordrecht, the Netherlands): $179-189$.

Remmelts, G., 1996. Salt tectonics in the southern North Sea, the Netherlands. In: Rondeel, H.E., Batjes, D.A.J. \& Nieuwenhuijs, W.H. (eds): Geology of gas and oil under the Netherlands. Kluwer Academic Publishers (Dordrecht, the Netherlands): 143-158.

Roelofsen, J.W. \& De Boer, W.D., 1991. Geology of the Lower Cretaceous Q/1 oil-fields, Broad Fourteen Basin, The Netherlands. In: Spencer, A.M. (ed.): Generation, accumulation and production of Europe's hydrocarbons. Special Publication of the European Association of Petroleum Geoscientists 1. Oxford University Press (Oxford, United Kingdom): 203-216. 
Roos, B.M. \& Smits, B.J., 1983. Rotliegend and Main Buntsandstein gas fields in Block K/13 - A case history. Geologie en Mijnbouw 62: 75-82.

Spain, D.R. \& Conrad, P.C., 1997. Quantitative analysis of top-seal capacity: offshore Netherlands, southern North Sea. Geologie en Mijnbouw 76: 217-226.

Sullivan, M.D., Haszeldine, R.S., Boyce, A.J., Rogers, G. \& Fallick, A.E., 1994. Late anhydrite cements mark basin inversion: isotopic and formation water evidence, Rotliegend Sandstone, North Sea. Marine and Petroleum Geology 11:46-54.

Tóth, J., 1995. Hydraulic continuity in large sedimentary basins. Hydrogeology Journal 3: 4-16.

Van Adrichem Boogaert, H.A. \& Kouwe, W.F.P., 1993-1997. Stratigraphic nomenclature of the Netherlands, revision and update by RGD and NOGEPA. Mededelingen Rijks Geologische Dienst 50.

Van Wijhe, D.H., 1987a. The structural evolution of the Broad Fourteens Basin. In: Brooks, J. \& Glennie, K. W. (eds): Petroleum Geology of north west Europe. Graham and Trotman (London, United Kingdom): 315- 323.
Van Wijhe, D.H., 1987b. Structural evolution of inverted basins in the Dutch offshore. Tectonophysics 137:171-219.

Verweij, J.M., 1999. Application of fluid flow systems analysis to reconstruct the post-Carboniferous hydrogeohistory of the onshore and offshore Netherlands. Marine and Petroleum Geology 16: 561-579.

Verweij, J.M. \& Simmelink, H.J., 2002. Geodynamic and hydrodynamic evolution of the Broad Fourteens Basin (The Netherlands) in relation to its petroleum systems. Marine and Petroleum Geology 19: 339-359

Verweij, J.M., Simmelink, H.J., David, P., Van Balen, R.T., Van Bergen, F. \& Van Wees, J.D.A.M., 2000. Geodynamic and hydrodynamic evolution of the Broad Fourteens Basin and the development of its petroleum systems: an integrated 2D basin modelling approach. Journal of Geochemical Exploration 69-70: 635-639.

Warren, E.A. \& Smalley, P.C., 1993. The chemical composition of North Sea formation waters: a review of heterogeneity and potential applications. In: Parker, J.R. (ed.): Petroleum Geology of Northwest Europe: Proceedings of the $4^{\text {th }}$ conference. The Geological Society (London, United Kingdom): 1347-1352. 